\title{
A giant 'sausage' thrombus in the left ventricle in a patient with preserved ventricular function
}

\author{
Hashir Kareem, ${ }^{1}$ Tom Devasia, ${ }^{1}$ Vasudev Baburaya Pai, ${ }^{2}$ Kapil Minocha ${ }^{3}$
}

\begin{abstract}
'Department of Cardiology, Kasturba Medical College, Manipal, Karnataka, India ${ }^{2}$ Department of Cardiac Surgery, Kasturba Medical College, Manipal, Karnataka, India

${ }^{3}$ Department of Cardiothoracic Surgery, Kasturba Medical College, Manipal, Karnataka, India
\end{abstract}

\section{Correspondence to} Dr Hashir Kareem, hashirkareem@gmail.com

Accepted 16 April 2014
CrossMark

To cite: Kareem $\mathrm{H}_{\text {, }}$ Devasia T, Pai VB, et al. BMJ Case Rep Published online: [please include Day Month Year] doi:10.1136/ bcr-2014-204362

\section{DESCRIPTION}

A 49-year-old man had presented to us 2 years ago with a history of recent anterior wall myocardial infarction which was treated at another hospital. An echocardiogram was performed which revealed mild regional wall motion abnormality involving the apical segments with good overall left ventricular (LV) function and normal ejection fraction. There was a small mass, measuring $1.1 \times 0.8 \mathrm{~cm}$, at the apex which was diagnosed to be an organised thrombus (figure 1 and video 1). He was started on anticoagulation and discharged. He was subsequently lost to follow-up. He presented almost 18 months later. He had discontinued oral anticoagulant medication. The echocardiogram was repeated which revealed the following astounding image (figure 2 and video 2 ).

A sausage-shaped, mobile mass, measuring $7.2 \times 1.3 \mathrm{~cm}$ was found in the left ventricle protruding from the apex, almost reaching the mitral valve. His LV function was normal with an ejection fraction of $65 \%$. He was scheduled for emergent surgical removal and biopsy of the mass. The mass was removed through a midline sternotomy followed by an LV incision on cardiopulmonary bypass. The mass measured $8 \times 2 \times 1.5 \mathrm{~cm}$ (figure 3 ).

He made a rapid recovery after the surgery and is currently on regular follow-up. Histopatholgical examination revealed fibrin admixed with red blood cells confirming it to be a thrombus. There was no evidence of malignancy.

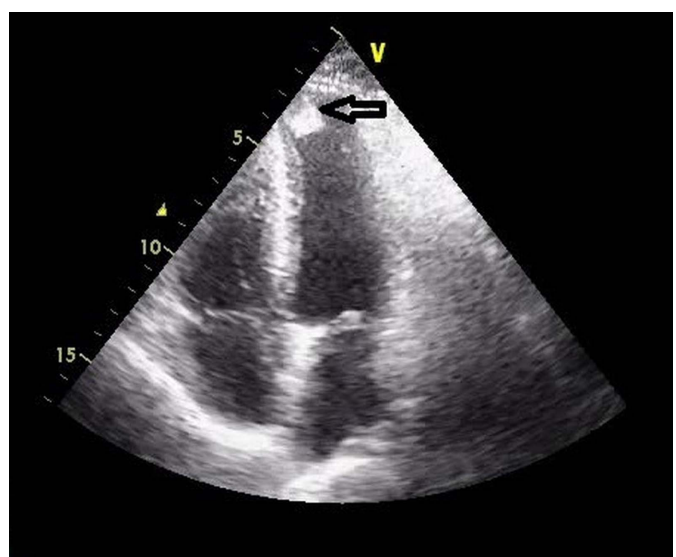

Figure 1 Apical four-chamber view of transthoracic echocardiogram showing a small organised mass (black arrow) at the apex of the left ventricle.

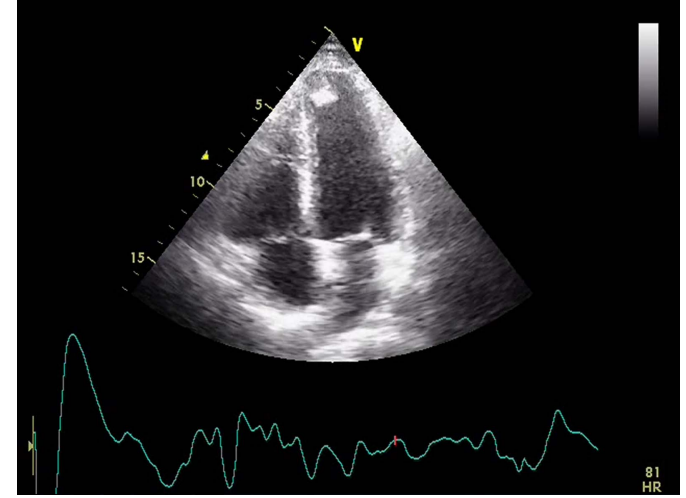

Video 1 Transthoracic echocardiogram showing apical wall motion abnormality and small organized thrombus at the left ventricular apex.

Major risk factors for the development of thrombus after a myocardial infarction include anterior wall infarction and LV ejection fraction less than $40 \% .^{12}$ Small apical infarcts and patients with normal LV function have occasionally been reported to develop thrombi. ${ }^{1}{ }^{3}$ However, the development of such a large thrombus in a patient with a small infarct and preserved LV function is very unusual.

The fact that the patient was lost to follow-up and defaulted on his anticoagulation medication

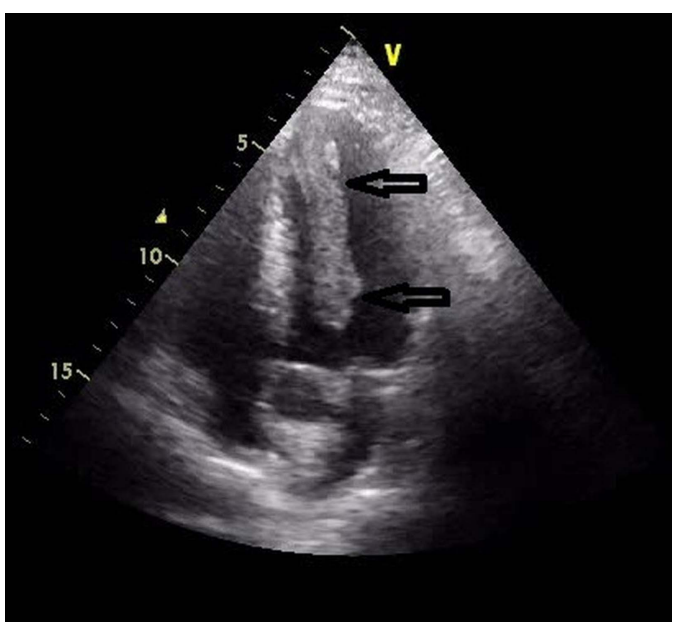

Figure 2 Apical four-chamber view of transthoracic echocardiogram showing a giant sausage-shaped mass (black arrows) arising from the apex of the left ventricle. 


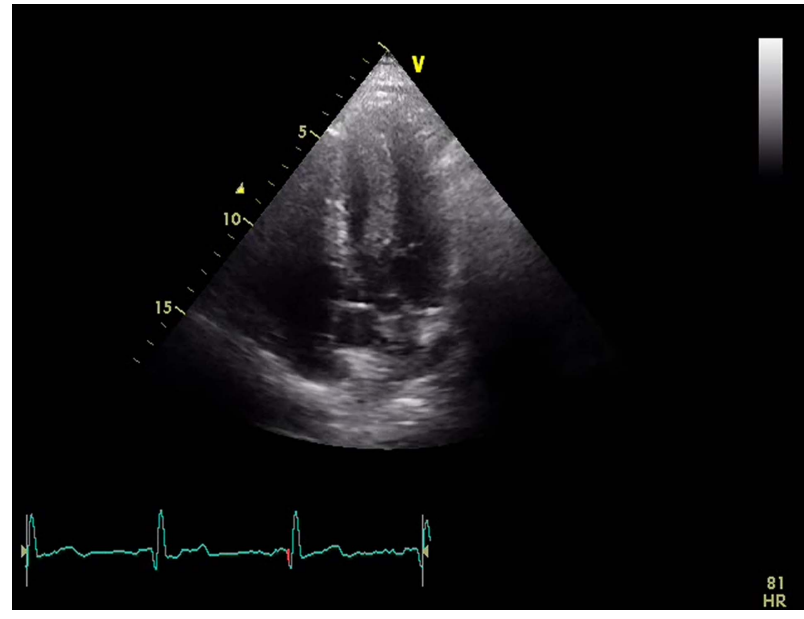

Video 2 Transthoracic echocardiogram showing a giant mobile thrombus arising from the left ventricular apex.

probably contributed to the development of such a large thrombus in this patient.
Learning points

A very large thrombus can rarely develop in a patient with a small infarct and preserved left ventricular (LV) function.

- Once a small thrombus is detected, proper anticoagulation with regular follow-up is mandatory even if the thrombus appears organised and LV function is good.

Competing interests None.

Patient consent Obtained.

Provenance and peer review Not commissioned; externally peer reviewed.

\section{REFERENCES}

1 Delewi R, Zijlstra F, Piek JJ. Left ventricular thrombus formation after myocardial infarction. Heart 2012;98:1743-9.

2 Keren A, Goldberg S, Gottlieb S, et al. Natural history of left ventricular thrombi: their appearance and resolution in the posthospitalization period of acute myocardial infarction. J Am Coll Cardiol 1990;15:790-800.

3 Kahya Eren N, Emren SV, Duygu $\mathrm{H}$, et al. Left ventricular thrombus formation in a patient with normal ejection fraction. Turk Kardiyol Dern Ars 2013;41: $625-8$.

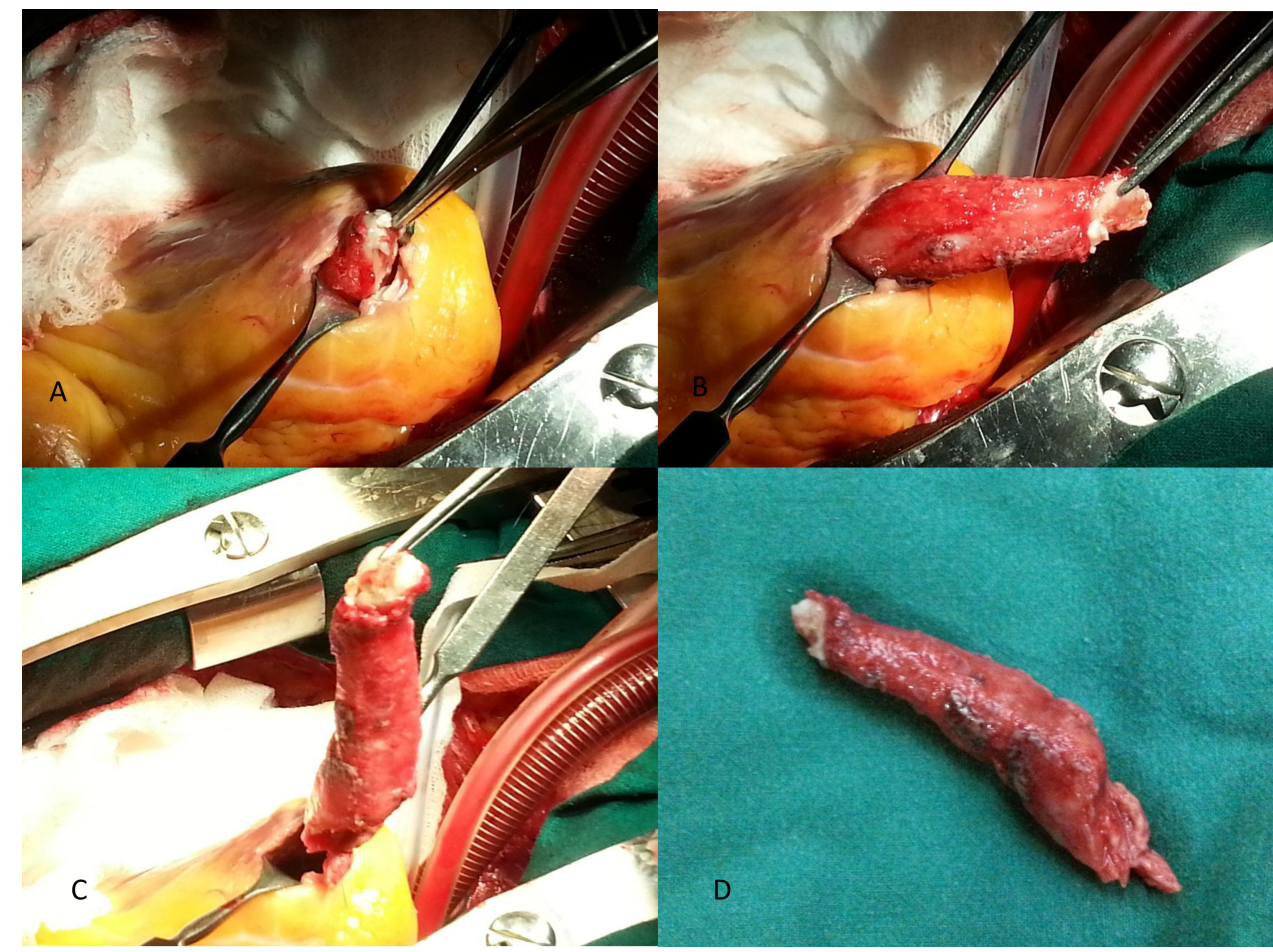

Figure 3 (A-D) Intraoperative pictures showing the mass being removed through a left ventricular incision. 
Copyright 2014 BMJ Publishing Group. All rights reserved. For permission to reuse any of this content visit http://group.bmj.com/group/rights-licensing/permissions.

BMJ Case Report Fellows may re-use this article for personal use and teaching without any further permission.

Become a Fellow of BMJ Case Reports today and you can:

- Submit as many cases as you like

- Enjoy fast sympathetic peer review and rapid publication of accepted articles

- Access all the published articles

- Re-use any of the published material for personal use and teaching without further permission

For information on Institutional Fellowships contact consortiasales@bmjgroup.com

Visit casereports.bmj.com for more articles like this and to become a Fellow 